\title{
Occurrence of multidrug resistance shiga-toxin producing Escherichia coli from milk and milk products
}

\author{
Javeed Ahmad Sheikh ${ }^{1}$, Mohd. Rashid ${ }^{1}$, Majueeb U Rehman ${ }^{1}$ and M. A. Bhat ${ }^{2}$
}

1. Division of Veterinary Public Health and Epidemiology, Sher-e-Kashmir University of Agricultural Sciences \& Technology, Jammu, J\&K-181102, India; 2. Division of Veterinary Microbiology and Immunology, Sher-e-Kashmir University of Agricultural Sciences \& Technology, Jammu, J\&K-181102, India.

Corresponding author: Mohd Rashid, email: rashidvph03@yahoo.co.in

Received: 06-09-2013, Revised: 30-09-2013, Accepted: 02-10-2013, Published online: 23-10-2013

doi: 10.14202 /vetworld.2013.915-918

How to cite this article: Sheikh JA, Rashid M, Rehman MU and Bhat MA (2013) Occurrence of multidrug resistance shigatoxin production Escherichia coli from milk and milk products, Veterinary World 6(11): 915-918.

\begin{abstract}
Aim: The aim of this study was to assess the hygienic quality of milk and milk products in respect of shiga toxin producing Escherichia coli (STEC).

Materials and Methods: 205 samples of raw milk and milk products were processed for isolation of $E$. coli. The isolates were screened by $\mathrm{mPCR}$ for detection of virulence gene. $52 \mathrm{E}$. coli isolates were tested against 15 commonly used antibiotics in the field.

Results: Of the 205 samples of milk and milk products $52(25.36 \%)$ were positive for $E$. coli. Out of which $4 \%$ samples were positive for STEC from raw milk and 3.64\% from milk products. Also, 25 of $52(48 \%)$ of E. coli isolates were multidrug resistance whereas $62.5 \%$ of STEC from milk and milk products were multidrug resistance.

Conclusions: The milk and milk products production is of poor hygienic quality in and around Jammu region which needs improvement.
\end{abstract}

Key words: milk, mPCR, multidrug resistance, STEC

\section{I ntroduction}

Shiga toxin producing Escherichia coli (STEC) are widely distributed in the intestinal flora of humans and warm blooded animals. Cattle, sheep and poultry birds are thought to be the reservoir for STEC [1], although other animals including goat, pigs, fowls, cats and dogs do harbour these bacteria. It has been reported that the transmission can occur through the contaminated milk and milk products [2]. The pathogenicity of STEC is associated with a number of virulence factors, including shiga toxins (encoded by the $s t x_{1}$ and $s t x_{2}$ genes), intimin (encoded by the eaeAgene), and the haemolysin (encoded by the hlyAgene) [3]. During the past decade STEC have emerged as a major food borne pathogen of public health concern responsible for mild diarrhea to Haemorrhagic colitis, Haemorrhagic uraemic syndrome (HUS) [4] and Thrombocytopenic purpura (TPP) [5] in humans. STEC is highly infectious organism and the infective dose may range between 10 to 50 organisms [6]. This was first recognized as a cause of illness in 1982 during an outbreak of severe bloody diarrhoea traced to food restaurants [7].

However, still the significance of milk and milk products as the source of STEC needs to be elucidated, particularly in Jammu region of Jammu and Kashmir state. Considering the impact of the STEC in veterinary and human medicine as an emerging food borne

Copyright: The authors. This article is an open access article licensed under the terms of the Creative Commons Attribution License (http://creativecommons.org/licenses/by/2.0) which permits unrestricted use, distribution and reproduction in any medium, provided the work is properly cited. pathogen, present study was carried out with the objectives to investigate occurrence of $E$. coli, virulence gene profile of STEC and antimicrobial susceptibility of E. coli isolates from milk and milk products.

\section{Materials and Methods}

The samples from foods of animal origin comprising 150 of raw milk (10 ml each), 30 of cheese (10 gm each) and 25 of kalaari (10 gm each) were collected twice a week in and around Jammu. The samples were collected in sterile containers and transported to laboratory over ice for further processing of $E$. coli. The isolation of E. coli was achieved by enrichment in MacConkey broth, followed by plating on Eosin Methylene Blue (EMB) agar (Hi Media, Mumbai, India). Suspected colonies were confirmed by standard microbiological techniques $[8,9]$.

The mPCR for detection of $s t x_{1}, s t x_{2}, e a e A$ and $h l y A$ virulence genes of the E.coli isolates was done as per the method of Paton and Paton [10]. The primers used are listed in Table-1. DNA amplification was performed in a thermal cycler (Master Cycler Gradiant, Eppendorf, Germany). PCR products were analyzed by agarose gel electrophoresis and the specific DNA bands were visualized using ethidium bromide staining under UV illumination.

The E. coli isolates obtained from the samples were examined for their antimicrobial drug susceptibility/resistance pattern by disc diffusion technique of Bauer, et al. [11]. The antibiotic discs used were obtained from Hi-Media Laboratories Pvt. Ltd. Mumbai. 
Table- 1. List of primers ( $\left.5^{\prime}-3^{\prime}\right)$ used in the mPCR reaction

\begin{tabular}{|c|c|c|c|}
\hline Primer & Sequence (5'-3') & Amplicon size & Reference \\
\hline$s t x_{1}-F$ & ATAAATCGCCATTCGTTGACTAC & $180 \mathrm{bp}$ & (10) \\
\hline$s x_{1}-R$ & AGAACGCCCACTGAGATCATC & & \\
\hline$s x_{2}-F$ & GGCACTGTCTGAAACTGCTCC & 255 bp & \\
\hline$s x_{2}-R$ & TCGCCAGTTATCTGACATTCTG & & \\
\hline eaeA-F & GACCCGGCACAAGCATAAGC & $384 b p$ & \\
\hline eaeA-R & CCACCTGCAGCAACAAGAGG & & \\
\hline hlyA-F & GCATCATCAAGCGTACGTTCC & $534 b p$ & \\
\hline hlyA-R & AATGAGCCAAGCTGGTTAAGCT & & \\
\hline
\end{tabular}

Table- 2. Occurrence of different virulence genes among the $\mathrm{E}$. coli isolates from milk and milk products

\begin{tabular}{|c|c|c|c|c|c|c|c|}
\hline \multirow{2}{*}{$\begin{array}{l}\text { Types of } \\
\text { samples analysed }\end{array}$} & \multirow{2}{*}{$\begin{array}{c}\text { No. of isolates } \\
\text { screened }\end{array}$} & \multicolumn{6}{|c|}{ No. of different types of genes } \\
\hline & & $\mathbf{s t x}_{1}$ & stx ${ }_{2}$ & $\mathrm{stx}_{1} \& \mathrm{stx}_{2}$ & Total STEC & eaeA & hlyA \\
\hline $\begin{array}{l}\text { Milk } \\
\text { Milk products } \\
\text { Total }\end{array}$ & $\begin{array}{c}46 \\
6 \\
52\end{array}$ & $\begin{array}{c}1(2.17) \\
0(0) \\
1(1.92)\end{array}$ & $\begin{array}{l}2(4.35) \\
2(33.33) \\
4(7.69)\end{array}$ & $\begin{array}{c}3(6.52) \\
0(0) \\
3(5.77)\end{array}$ & $\begin{array}{l}6(13.04) \\
2(33.33) \\
8(15.38)\end{array}$ & $\begin{array}{l}4(8.69) \\
2(33.33) \\
6(11.54)\end{array}$ & $\begin{array}{l}6(13.04) \\
1(16.67) \\
7(13.46)\end{array}$ \\
\hline
\end{tabular}

Numbers in parenthesis indicate percentages

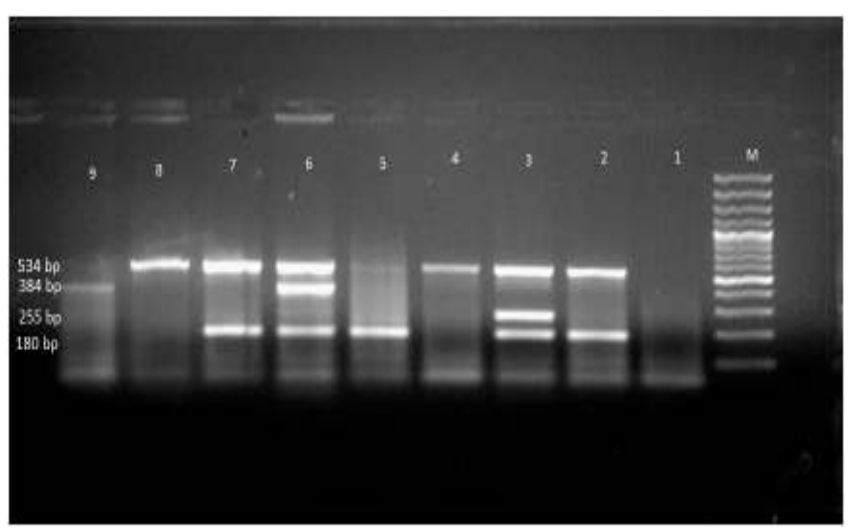

Figure-1. Agarose gel showing $\mathrm{MPCR}$ amplification products of $\mathrm{stx}_{1}, \mathrm{stx}_{2}$, eaeA and hlyA genes in $\mathrm{E}$. coli isolate,

Lane M: 100 bp Molecular weight marker,

Lane 1: negative Control,

Lane 2, 7: Amplified products of stx $x_{1}$ and hlyA genes,

Lane 3: Amplified products of stx $_{1}$, stx ${ }_{2}$ and hlyA genes,

Lane 4, 8: Amplified product of hlyA gene,

Lane 5: Amplified product of stx ${ }_{1}$ gene,

Lane 6: Amplified products of stx $_{1}$, eaeA and hlyA genes,

Lane 9: Amplified products of eaeA genes.

The isolates were tested against 15 commonly used

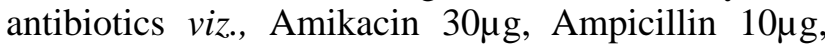
Amoxicillin $10 \mu \mathrm{g}$, Cefotaxime $30 \mu \mathrm{g}$, Cefixime 5 $\mathrm{\mu g}$,

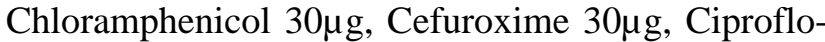
xacin $5 \mu \mathrm{g}$, Co-trimoxazole $25 \mu \mathrm{g}$, Gentamicin $10 \mu \mathrm{g}$, Nalidixic acid $30 \mu \mathrm{g}$, Norfloxacin $10 \mu \mathrm{g}$, Tetracycline $30 \mu \mathrm{g}$, Kanamycin $10 \mu \mathrm{g}$, and Streptomycin $10 \mu \mathrm{g}$.

\section{Results and Discussion}

Due to ability of STEC to cause outbreaks of fatal illness, many studies have been conducted in different parts of the globe. In the present study, 46 of 150 $(30.66 \%)$ milk and 6 of $55(10.90 \%)$ milk product samples were found contaminated with E. coli. Similar results were obtained by Daood, [12] who reported the prevalence of $E$. coli in milk $(35.45 \%)$ and in sweet cheese $(7.14 \%)$. Also similar results were obtained by Rashid, et al. [13], who reported $33.96 \%$ in milk and $14.89 \%$ in milk product samples. However, our findings are in contrast with those of Soomro, et al. [14] whose results revealed prevalence of $E$. coli in milk and milk products to be 51.66 and $57 \%$ respectively. Similarly, Ali and Abdelgadir [15] screened 100 raw milk samples from different localities/sources of Khartoum State. Their results revealed 63 percent of the samples to be positive for E. coli. High prevalence of $E$. coli was reported in different types of milk by many researchers $[16,17]$.

The presence of different types of genes among $E$. coli isolate are shown in Table-2. Eight of $52(15.38 \%)$ isolates from milk and milk products were possessing $s t x_{1}$ and or $s t x_{2}$ genes (Fig.1) as detected by PCR and designated as STEC. The results of the present study are in agreement with the findings of Rashid, et al. [13] where $16.98 \%$ of STEC were found in milk and $8.51 \%$ in milk products.

Varying prevalence of STEC in milk and milk products has also been reported by other workers. These include: $0.87 \%$ in raw milk samples of cattle [18]; $33.5 \%$ in raw milk from Malaysia [19]; $3.3 \%$ in milk samples from Brazil [20] and 0.75-16.2\% in various dairy products [21]. This might be due to varying hygienic milking practices being followed. However, a total of $52 \mathrm{E}$. coli isolates comprising of 46 isolates from milk and 6 from milk products were tested for their antibiotic sensitivity/resistance pattern to various antibiotics. Twenty five of $52(48 \%)$ isolates from milk and milk products showed multidrug resistance to three or more antibiotics. Chloramphe-nicol was the most effective with $83 \%$ sensitivity followed by Norfloxacin with $80 \%$ sensitivity observed among the isolates. Further, $74 \%$ Ciprofloxacin and Co-trimoxazole, $60 \%$ to Gentamicin, 54\% Nalidixic acid was sensitive. Whereas $68 \%$ of isolates were resistant to Amikacin, 67\% to Amoxycillin, 60\% to Ampicillin, Cefiximeand Kanamycin.

The results of our study show varying antibiotic sensitivity pattern of $E$. coli in milk and milk products as compared to reports of other researchers. Daood [12] 
studied the antibiotic resistance pattern of $E$. coli in milk and milk products. The resistance was observed against Ciprofloxacin (0\%), Gentamicin and Chloramphenicol (3.28\%), Tetracycline (16.39\%), Amoxicillin/ Clavulanic acid (92.26\%), Ampicillin (95.08\%), Cefoxitin (96.76\%), Cephazoline (97.54\%), Cephalothin (98.36\%) and Sulfamethoxazole/Trimethoprim(100\%). The highest resistance was reported against Tetracycline (92.2\%), followed by that to Streptomycin $(90.4 \%)$ and Nalidixic acid (88.3\%); lower resistance to Amoxicillin/Clavulanic acid and Ceftriaxone were detected in $14.2 \%$ and in $17.7 \%$ of the isolates, respectively by Rangel and Marin [22].

Resistance to Ampicillin and Gentamicin was the most common finding (44.4\%), followed by resistance to Erythromycin (33.3\%), Amoxicillin (11.1\%), Tetracycline $(11.1 \%)$ and Nalidixic acid (11.1\%) observed by Rahimi, et al. [23]. The highest resistance observed to Tetracycline, Penicillin, and Enrofloxacin with the frequency rate of 58.82, 46.07 and $45.09 \%$ respectively, as well as the lowest resistance to Nitrofurantoin and Ciprofloxacin with the frequency rate of 3.92 and $7.84 \%$ was observed by Momtaz, et al. [24]. So findings of our study differed from the findings of other workers. It could be assumed that the resistance pattern of $E$. coli had changed with respect to antimicrobial drugs being used in the area both in animals and human beings. Further the drug resistance attribute is mediated through plasmids, however, needs further confirmation.

\section{Conclusions}

On the basis of present results, it could be concluded that the microbial quality of milk and milk products sold in retails shops/local markets of Jammu area is not satisfactory. It is suggested that the raw milk and milk products should be handled under strict hygienic condition with constant microbial monitoring and stored in cool places to avoid recontamination and to safeguard the health of consumers. With a large population rearing cattle in this area, public health awareness including safe and hygienic practices while handling cattle or their products would be paramount importance in reducing the STEC infections in humans. Moreover, to prevent the reduced risk, the incorporation and consistent application of good manufacturing practices and hazard analysis of critical control points at every stages of food chain, from farm to retailer by those involved with handling and processing raw milk and milk products in both manufacturing and home environment should be followed.

\section{Authors' contributions}

JA has carried out the research work, MR guided the student to carry out the work and prepared the draft of the research work, MUR helped in collection of samples. MAB finalized the research plan and revised the manuscript. All authors read and approved the final manuscript.

\section{Acknowledgements}

The authors are thankful to Prof. S.A.Wani, Head
Division of Veterinary Microbiology and Immunology SKUAST Kashmir for facilitating this work. We are highly thankful to Hon'ble Vice Chancellor and Director Education SKUAST- Jammu, for providing the financial help to carry out the study.

\section{Competing interests}

The authors declare that they have no competing interests.

\section{References}

1. Solomakos, N., Govaris, A., Angelidis A. S. (2009) Occurrence, virulence genes and antibiotic resistance of Escherichia coli $\mathrm{O} 157$ isolated from raw bovine, caprine and ovine milk in Greece. Food Microbiology, 26: 865-871.

2. Armstrong, G.L., Hollingsworth, J. and Morris, J.G.J. (1996) Emerging food borne pathogen: E. coli O157:H7 as a model of entry of a new pathogen into the food supply of the developed world. Epidemiology Review, 18: 29-51.

3. Karch, H., Schmidt, H., Brunder, W. (1998) Plasmidencoded determinants in E.coli O157:H7.in:kaper, J.B., O, Brien, A.D., (Eds), E.Coli o157:H7 and other shiga toxin producing E.coli strains. ASM press, Washington, D.C., pp.183-194.

4. Griffin, P.M. and Tauxe. R.V. (1991)The epidemiology of infections caused by Escherichia coli $\mathrm{O} 157: \mathrm{H} 7$, other enterohaemorrhagic E. coli, and the associated hemolytic uremic syndrome. Epidemiology Review, 13:60-98.

5. Griffin, P.M. (1995)Escherichia coli O157: H7 and other hemorrhagic E. coli. In infection of the gastrointestinal tract, edited by M.J. Blaser, P.D. Smith, J.I. Ravdin, H.B. Greenberg and R.I. Guerrant, pp. 739-761,New York, N.Y. Raven Press, Ltd.

6. Health protection agency (2010) Identification of E. coli O157. National standard method BSOP ID 22 issue 3. http://www.hpa-standardmetods.org.uk/pdf_sops.asp, Accessed on 1st Sept 2013.

7. Riley, L.W., Remis R.S., Helgerson S.D., McGee, H.B., Wells, J.G., Gavis B.R., Hebert R.J., Olcott E.S., Johnson, L.M., Hargrett, N.T., Blake, P.A. and Cohen, M.L. (1983) Haemorrhagic colitis associated with rare Escherichia coli Serotypes. New England Journal of Medicine, 308: 681-685.

8. Hitchins, A.D., Hartman, P.A., Todd, E.C.D. (1992) Coliform Escherichia coli and its toxins. In: Vanderzant, c., Splittstoesser, D. (Eds), compendium of methods for the Microbiological Examination of foods. pp. 327-329. Compiled by the APHA Technical Committee on Microbiological Methods for Foods.

9. Quinn, P.J., Carter, M.E., Markey, B.K. and Carter, G.R. (1994) Clinical Veterinary Microbiology, pp. 21-26 and 209236. Published by Wolfe Publishing, an imprint of MosbyYear Book Europe Limited Printed in Spain by Grafos, S.A. Arte SobrePapel ISBN 0723417113.

10. Paton, A.W., and Paton,J.C. (1998) Detection and characterization of Shiga toxigenic Escherichia coli by using multiplex PCR assays for $s t x_{1}, s t x_{2}, e a e A$, enterohemorrhagic E. coli hlyA, $r f b_{0111}$, and $r f b_{0157}$. Journal of Clinical Microbiology, 36:598-602.

11. Bauer, A.W., Kirby, W.M.M., Sherris, J.C. and Turck, M. (1966) Antibiotic susceptibility testing by a standardized single disc method. American Journal of Clinical Pathology, 45(4): 493-496.

12. Daood, N. (2007) Detection and antimicrobial susceptibility of E.coli O157: H7 in raw bovine milk, some of dairy products and water samples. Damascus University Journal for BasicSciences, 23:1-15.

13. Rashid, M., Kotwal, S.K., Malik, M.A and Singh, M. (2013) Prevalence, genetic profile of virulence determinants and multidrug resistance of $E$. coli isolates from foods of animal origin, Vet. World 6(3):139-142.

14. Soomro, A.H., Arain, M.A., Khaskheli, M. and Bhutto, B. 
(2002)Isolation of Escherichia Coli from Raw Milk and Milk Products in Relationto Public Health Sold under Market Conditions at Tandojam. Pakistan Journal of Nutrition, 1(3): 151-152.

15. Ali, A. A. and Abdelgadir, W.S. (2011) Incidence of Escherichia coli in Raw Cow's Milk in Khartoum State. British Journal of Dairy Sciences, 2(1): 23-26.

16. Adesiyun, A.A. (1994) Bacteriological quality and associated public health risk of pre-processed bovine milk in Trinidad. International Journal of Food Microbiology, 21:253-261.

17. Njage, P.M.K., Jans, C., Wangoh, J., Lacroix, C. and Meile,L. (2012) Detection, isolation and molecular characterisation of Shigatoxigenic $\mathrm{O} 157$ and non-O157 Escherichia coli in raw and fermented camel milk. African Journal of Microbiology, 6(31):6031-6038.

18. Steele, M.L., Mcnab, W.B., Poppe, C., Griffiths, M.W., Chen, S., Degrandis, S.A., Eruhner, L.C., Larkin, C.A., Lynch, J.A. and Odumeru, J.A. (1997) Survey of Ontario bulk tank raw milk for food-borne pathogens. Journal of Food Protection, 60: 1341-1346.

19. Chye, F.Y., Abdullah, A., Ayob, M.K. (2004) Bacteriological quality and safety of raw milk in Malaysia. Food Microbiology, 21:535-541.

20. Vicente, H.I.G., Amaral, L.A., Cerqueira, A.M.F. (2005) ShigatoxigenicEscherichia coli serogroups O157, O111 and O113 in feces, water and milk samples from dairy farms. Brazil journal Microbiology, 36: 217-222.

21. Hussein, H.S., Sakuma, T. (2005) Prevalence of Shiga toxin producing Escherichia coli in dairy cattle and their products. Journal Dairy Science, 88: 450-465.

22. Rangel P. and Marin, J.M. (2009)Analysis of Escherichia coli isolated from bovine mastitic milk. Pesquisa Veterinaria Brasileira, 29(5): 363-368.

23. Rahimi, E., Chaleshtori, S.S. and Parsaei, P. 2011.Prevalence and antimicrobial resistance of Escherichia coli $\mathrm{O} 157$ isolated from traditional cheese, ice cream and yoghurt in Iran. African Journal of Microbiology Research, 5(22): 3706-3710.

24. Momtaz, H., Farzan, R., Rahimi, E., Dehkordi, F.S. and Souod, N. (2012) Molecular Characterization of Shiga Toxin-Producing Escherichia coli Isolated from Ruminant and Donkey Raw Milk Samples and Traditional Dairy Products in Iran. The Scientific World Journal, 10:1-13.

$* * * * * * * *$ 